\title{
Diyalojik Paydaş İletişimi İçin Twitter Kullanımı
}

The Usage of Twitter for Dialogic Stakeholder Communication

\section{Dr. Öğr. Üyesi H. Buluthan Çetintaş ${ }^{1}$}

Başvuru Tarihi: 26.03.2019

Kabul Tarihi: 13.09.2019

Öz

Konuşma, anlaşma ve uyum sağlama anlamına gelen diyalog, örgütsel iletişim çabalarının temelini oluşturmaktadır. Aslında tüm iletişim stratejileri diyalog kökenlidir ve diyalojik iletişimle kurum için değer yaratmak amaçlanmaktadır. Kent ve Taylor (1998), diyalojik iletişim kavramını, bir işletmenin ve paydaşlarının etkileşimli olarak iletişim kurabilecekleri bir araç olarak ortaya koymuştur. Buradaki temel düşünce, paydaşlar arasında bir anlayış ve anlam geliştirmek, onları belirli örgütsel hedeflere teşvik etmektir. Çalışmanın amacı, işletmelerin paydaşları ile diyalog oluşturmasını ve ilişkiler geliştirmesini incelemek, diyalojik iletişim uygulamalarının etkinliğini belirlemektir. Bu kapsamda İstanbul Sanayi Odasının İSO 500 listesinde yer alan 100 işletme örneklemi oluşturmaktadır. Diyalojik iletişim için en uygun sosyal medya aracı olan Twitter, uygulama alanı olarak seçilmiştir. Belirlenen işletmelerin Twitter hesaplarına ulaşılmış ve bu hesaplar incelenmiştir. Değerlendirmeye uygun olan 77 işletmenin Twitter hesabından toplam 770 mesaj alınmış ve mesajlar, içerik analizine tabi tutulmuştur. İçerik analizinde Kent ve Taylor (1998) tarafindan geliştirilen kodlama şemasından yararlanılmış ancak şemada çeşitli düzenlemeler yapılmıştır. Elde edilen sonuçlara göre işletmelerin Twitter'in diyalojik iletişim özelliklerinden faydalanmadiğını ve bu özellikleri kullanmadiğını söylemek mümkündür.

Anahtar Kelimeler: Kurumsal iletişim, ilişkisel yaklaşım, halkla ilişkiler, çevrimiçi iletişim, sosyal medya

\begin{abstract}
Dialogue, which means speech, agreement and adaptation, forms the basis of organizational communication efforts. In fact, all communication strategies are based on dialogue, and are intended to create value for organization through dialogue. Kent ve Taylor (1998) demonstrated the concept of dialogic communication as a tool for companies and their stakeholders to communicate interactively. The main idea is to develop an understanding or meaning among stakeholders and encourage them to achieve specific organizational goals. Aim of the study is to
\end{abstract}

${ }^{1}$ Atatürk Üniversitesi Edebiyat Fakültesi, bcetintas@gmail.com, ORCID: 0000-0002-1734-5174 
examine how companies establish dialogue and develop relations with their stakeholders and determine the effectiveness of dialogic communication applications. In this context, 100 companies in the ISO 500 list were selected as samples. Twitter was selected as the appropriate application medium. Companies' Twitter accounts have been reached and examined, 770 messages were received from Twitter accounts of 77 companies and messages were subjected to content analysis. In content analysis, the coding scheme developed by Kent ve Taylor (1998) was used but various arrangements were made. According to the results, companies don't utilize Twitter's dialogic communication features and do not use them.

Keywords: Corporate Communication, Relational Approach, Public Relations, Online Communication, Social Media

\section{Giriş}

Halkla ilişkiler, bir işletme ile başarısının veya başarısızlığının bağlı olduğu halklar arasında karşlıklı olarak faydalı ilişkiler kuran ve sürdüren bir yönetim işlevidir (Cutlip, Center ve Broom, 1985, s.4). Halkla ilişkilerin iletişim yönetimi, ilişki kurma ve diyalog geliştirme şeklinde üç genel amacı vardır. Kurumla iç ve dış paydaşları arasında karşılıklı ilişkiler kurmak, kurum kimliğine, kurum imajına ve kurumsal itibara dayanmakta ve bu unsurlara göre şekillenmektedir. Dolayısıyla işletmeler, paydaşlarıyla ilişkilerini korumak için farklı paydaş gruplarıyla nasıl iletişim kuracaklarını belirlemelidir (Stephens ve Malone, 2009, s.231). Bu nedenle, halkla ilişkilerin hedefi, kurumla paydaşları arasında gerçekleşen etkileşimi, kurumsal misyon, vizyon ve stratejik amaçlar doğrultusunda yönlendirmek olmalıdır.

Paydaş iş birliği, bir işletmenin toplumun ortak kaygılarına yönelik konularda paydaşlarıyla birlikte çalışarak, uzun vadeli ilişkiler kurmasıdır (Cornelissen, 2014, s.282). İşletmelerin paydaşlarıyla iş birliği yapabilmesinin yolu, onlarla ilişki kurması ve bu ilişkinin devamlı iletişim ve etkileşim ile sürdürülebilmesidir. Kurulan ve karşıllklı yarar sağlayan bu ilişkiler, diyalojik iletişime dayanmaktadır. Zira diyalog, anlayışı, paylaşımı ve ortak kabulleri artırmak, iş birliğini geliştirmek, örgütsel kararların ve eylemlerin kalitesini arttırmak gibi amaçlara yönelik eylemlerdir. Stratejik diyaloglar, işletmelerin önemli paydaşlarını örgütsel karar süreçlerine dahil etmelerine izin vererek sosyal kabulü ve meşruiyeti artırmaktadır (Christensen, Morsing ve Cheney, 2008, s.49).

İş dünyasında son yllarda paydaşlara yönelik diyalog ve taahhüt kavramları önemli araştırmalar ve mesleki konularda olarak ortaya çıkmaktadır (Gutiérrez-García, Recalde ve Piñera-Camacho, 2015, s.744). Öte yandan işletmeler, sosyal paylaşım sitelerinin kamu yararını sağlamadaki gücünü anlamışlardır (Abitbol ve Lee, 2017, s.797) ve bu ortamları, iletişim hedeflerine erişmek, paydaşlarına ulaşmak ve onlarla ilişkiler kurmak gibi çeşitli örgütsel iletişim çalışmalarında uygulamaktadırlar (Argenti, 2006; Pollach, 2005; Rybalko ve Seltzer, 2010). Zira bu araçlar, paydaşları dinlemek, onları konuşmaya dahil ederek ilişkiler kurmak ve 
örgütsel bilgileri yaymak için kullanışlı ve önemli ortamlardır (Bortree ve Seltzer, 2009; Waters ve Lemanski, 2011).

İşletmelerin çeşitli sosyal medya ortamlarını nasıl kullandıklarını ve bu tür bir medyayı diyalojik biçimde kullanıp kullanmadıklarını anlamak için daha fazla araştırma yapılması gerekmektedir (Linvill, McGee ve Hicks, 2012, s.636). Bu kapsamda çalışma, işletmelerin Twitter’’ kullanarak paydaşları ile diyalog oluşturmasını ve ilişkiler geliştirmesini incelemek, diyalojik iletişim uygulamalarının etkinliğini belirlemek üzere hazırlanmıştır. Çalışmanın dört araştırma sorusu bulunmaktadır. Bu sorular şöyledir:

AS.1. İşletmelerin Twitter profillerindeki diyalog özellikleri nelerdir?

AS.2. İşletmelerin Twitter hesaplarındaki mesajların diyalog özellikleri nelerdir?

AS.3. İşletmelerin Twitter hesaplarındaki mesajların diyalog ilkeleri nelerdir?

AS.4. İşletmelerin Twitter hesaplarındaki hedef kitleler kimlerdir?

\section{Diyalog ve Diyalojik İletişim}

Diyalog, müzakere edilen fikir ve görüş alışverişidir (Kent ve Taylor, 1998, s.325). Karşılıklı dürüst, açık ve etik temelli bir ilişki içinde olan tarafların çabalarını temsil etmektedir (Bortree ve Seltzer, 2009, s.317). Diyalog, halkla ilişkilerde söylemekten ve ikna etmekten ziyade güvene ve bağlılığa dayanan, karşılıklı gerçekleştirilen bir yaklaşımdır (Capozzi ve Zipfel, 2012). İletişim içeriğinin ve çıtılarının işletme yönetimince kontrol edilmediği, devamlılık arz eden bir iletişim süreci (Theunissen ve Noordin, 2012, s.11) olan diyalog, ilişkisel iletişim disiplininin kökeninde bulunan ve diyalojik iletişim prosedürlerinden kaynaklanan özel bir sonuç ya da çıtıdır (Kent ve Taylor, 2002).

Diyalog, yapısı itibariyle ilişkiler geliştirmek istemektedir (Coombs ve Holladay, 2010) ancak ilişki geliştirmek için diyalog kurmak, kurumun genel iletişim yaklaşımının bir parçası olması ile gerçekleşebilecektir zira bu, tek seferlik bir girişim değildir. Dolayısıyla diyalog, ilişkilerin bir parçası olarak görülmeli, bilgi ve anlayışı oluşturmanın bir aracı olarak kabul edilmelidir. İdeal olan kurumların kitle iletişim araçlarını ve yeni medyayı kullanarak daha fazla halkla etkileşime geçmesi, kurum ve paydaş arasındaki diyaloğu kolaylaştıracak uygun bir yaklaşım sergilemesidir (Theunissen ve Noordin, 2012, s.9-10).

Diyalog teorisi, işletmelerin etkin örgüt-paydaş iletişim kanalları oluşturması için paydaşlarıyla dürüst ve etik yollarla etkileşime girmeye istekli olmaları gerektiğini savunmaktadır (Botan, 1997). Bu istekte olan işletmeler için halkla ilişkilerin temel bileşenlerinden biri haline gelen (Shin, Pang ve Kim, 2015, s.192) çevrimiçi medya ortamlarının önemi giderek artmaktadır çünkü bu ortamlar, işletmelere önemli kitleleri ile etkileşimde bulunabilecekleri ve kullanıcıların ilgi duydukları konularda birbirleriyle etkileşim kurabilecekleri bir alan sağlamaktadır. Bu durum, diyalojik iletişimi teşvik etmek için gerekli olan ideal koşulları sağlamaktadır (Bortree ve Seltzer, 2009, s.317).

Facebook ve Twitter gibi araçların herkes tarafından erişilebilir hale gelmesiyle bu araçlar, çevrimiçi diyalojik iletişimi geliştirmek üzere kurumsal iletişim stratejilerine dahil edilmiştir 
(Shin, Pang ve Kim, 2015, s.188). Twitter, fotoğraf, video ya da bağlantı paylaşmak, örgütsel haberleri ya da gelişmeleri duyurmak için uygun bir iletişim kanalıdır (Swani, Milne, Cromer ve Brown, 2013, s.48). Çevrimiçi medya, işletmelere karşılıklı iletişim için çeşitli özellikler ve araçlar sunmaktadır. Sunulan bu imkanlarla kullanıcı katılımı sağlanabilmekte böylece olumlu sonuçlar veya çıtılar alınabilmektedir (Shin, Pang ve Kim, 2015, s.208).

Diyalojik iletişim faaliyetleri ile işletmeler, paydaşlarının seslerini biraraya getirmekte, bu şekilde örgütsel planları ve kararları için gerekli toplumsal onayı almayı ummaktadır (Christensen, Morsing ve Cheney, 2008, s.49). Ancak diyalojik sistemlerin işletmelere nasıl uygulanacağının cevabını vermek kolay değildir. Zira diyalog, karmaşık ve çok yönlü bir süreçtir. Diyalog kurma süreci, paydaş ihtiyaçlarını belirleme ve karşılama konusunda bir yaklaşımdır. Diyalojik iletişim uygulaması, paydaşların ve işletmelerin birbirlerini daha iyi anlamaları ve iletişim kurmaları için temel kurallara sahip olma olasılı̆̆ını artırmaktadır (Kent ve Taylor, 2002, s.33).

\section{Yöntem}

Literatür: Halkla ilişkiler alanında diyalojik iletişim ile ilgili birçok çalışma yapılmıştır. $\mathrm{Bu}$ çalışmalar arasında kavramsal olanlar (Özoran, 2017), işletmelerin web sayfalarına yönelik olanlar (Aslan, 2017; Eray ve Aslan, 2016; Gordon ve Berhow, 2009; Özdemir ve Yamanoğlu, 2010) ve yine işletmelerin sosyal medya uygulamalarına yönelik olanlar (Bortree ve Seltzer, 2009; Rybalko ve Seltzer, 2010; Türkal ve Güllüpunar, 2017; Yağmurlu, 2013) bulunmaktadır. Twitter, işletmelerin paydaşlarıyla diyalojik iletişim kurmaları ve ilişkilerini geliştirmelerini sağlayan mükemmel bir iletişim ortamı olarak kabul edildiği (Kwon ve Sung, 2011; Rybalko ve Seltzer, 2010) için literatürdeki pek çok çalışma gibi bu çalışmanın uygulama ortamı olarak Twitter belirlenmiştir.

Örneklem: Örneklemi, İstanbul Sanayi Odasının belirlediği İSO 500 listesinde yer alan işletmeler oluşturmaktadır. Listede yer alan 500 işletme içinden 100 işletme, sistematik örnekleme ile seçilmiştir. İkinci aşamada, 100 işletmenin tamamının Twitter hesaplarına ulaşılmış ve hesaplar incelenmiştir. Hesabında en az 20 mesaj olan (aktif kullanım) ve son bir ay içinde en az bir mesajı bulunan (güncellik) işletmeler belirlenmiştir. Bunun sonucunda 77 işletmenin Twitter hesabı değerlendirmeye alınmıştır.

Yöntem: Çalışmada, belirlenen 77 işletmenin her birine ait Twitter hesabındaki son 10 mesaj alınmış. Mesajlar, 2018 yılının aralık ayında yayınlananlar arasından seçilmiştir. Toplamda 770 mesaj, içerik analizine tabi tutulmuştur. İçerik analizinde, Kent ve Taylor (1998) tarafından geliştirilen ve çeşitli araştırmacıların (McAllister, 2012; Rybalko ve Seltzer, 2010; Waters ve Jamal, 2011) kullandığı bir kodlama şemasından yararlanılmıştır. Kent ve Taylor (1998), bir web sayfası değerlendirmek üzere 4 başlıktan (Bilginin yararlılğ̆ı, tekrar ziyaretlerin korunması, tekrar ziyaretlerin sağlanması ve diyalog döngüsü) oluşan kodlama şemasını geliştirmiştir. Ancak bunlardan Arayüz kolaylı̆̆ı maddesi, Rybalko ve Seltzer (2010)'de olduğu gibi Twitter'a uygun olmadığı için alınmamıştır. Çalışmanın araştırma sorularına yanıt bulmak amacıyla 
Twitter profilleri, mesajların diyalog ilkeleri, mesajların diyalojik özellikleri ve hedef kitleler olarak dört inceleme yapılmıştır. Bu incelemelerde Rybalko ve Seltzer (2010)'den yararlanılmış ancak bazı değişiklikler yapılmıştır.

Sınırlılıklar: Çalışmanın birtakım sınırlılıkları bulunmaktadır. Öncelikle çalışmanın örneklemini, İstanbul Sanayi Odasının İSO 500 listesinde yer alan 100 işletme oluşturmaktadır. Ayrıca çalışmada sadece işletmelerin Twitter hesaplarında bulunan mesajları incelenmiş ve değerlendirmeler bu mesajlara göre yapılmıştır.

\section{Bulgular}

Çalışmada elde edilen veriler, araştırma soruları bağlamında ele alınmıştır. Bu kapsamda araştırma sorularına (AS) yönelik elde edilen sonuçlar aşağıda verilmiştir.

\section{AS.1: Profillerin diyalog özellikleri}

Twitter'da bulunan profil, bireylerin ya da işletmelerin kendilerini tanıttıkları, kendileri hakkında kısa da olsa bilgi verdikleri kısımdır. Bu kısım, diyolojik özellik taşıması nedeniyle değerlendirmeye alınmıştır. İşletmelerin profilleri, 7 başlıkta (Web sayfasına bağlantı, işletmenin kısa açıklaması, işletme sloganı, işletme yeri, doğrudan mesaj, diğer bağlantılar ve diğer diller) değerlendirilmiştir. 77 işletme profili içinde 3 işletme profilinde herhangi bir bilgi bulunmamaktadır. 74 profil incelendiğinde, bu profillerde web sayfasına bağlantı $(\mathrm{n}=72)$, işletmenin kısa açıklaması $(\mathrm{n}=24)$, işletme sloganı $(\mathrm{n}=16)$, işletme yeri bilgisi $(\mathrm{n}=34)$, doğrudan mesaj $(\mathrm{n}=33)$, diğer bağlantılar $(\mathrm{n}=7)$ ve diğer diller $(\mathrm{n}=5)$ ve bulunmaktadır.

\section{AS.2: Mesajların diyalog özellikleri}

İkinci araştırma sorusu kapsamında işletmelerin Twitter hesaplarında paylaştıkları mesajlar değerlendirilmiştir. Değerlendirmede toplam 770 mesaj içeriği incelenmiş, mesajların diyalog özellikleri 6 başlıkta (İşletme hakkında önemli bilgi, bir soru ile diyaloğu teşvik etme, önemli gün kutlama, işletme hakkında çıkan haberler, sektörel haberler ve belirli bir kişiye cevap verme) belirlenmeye çalışılmıştır. Mesajlarda en çok görülen içerik işletme hakkında önemli bilgi $(\mathrm{n}=347)$ olmuştur. İkinci sırada, bir soru ile diyaloğu teşvik etme $(\mathrm{n}=154)$ yer almaktadır. Sonrasında önemli gün kutlama $(\mathrm{n}=137)$, işletme hakkında çıkan haberler $(\mathrm{n}=108)$ ve sektörel haberler $(\mathrm{n}=24)$ gelmektedir. Belirli bir kişiye cevap verme $(\mathrm{n}=0)$ ile ilgili içeriğe rastlanmamıştır.

\section{AS.3: Mesajların diyalog ilkeleri}

Üçüncü araştırma sorusu, mesajların diyalog ilkelerini ortaya koymaya ve mevcut ilkeleri belirlemeye yöneliktir. Bu doğrultuda mesajlar, 4 başlıkla (Bilginin yararlllğ̆l, tekrar ziyaretlerin korunması, tekrar ziyaretlerin sağlanması ve diyalog döngüsü) değerlendirilmiştir.

\section{a. Bilginin yararlılı̆̆}

Bilginin yararlılı̆̆ı, medya, yatırımcı ve müşteri olarak üç kısımdan oluşmaktadır. Bu üç başlık altında paylaşılan bağlantılar (link) ele alınmıştır. Müşteri, işletmenin web sayfasında yer alan kariyer sayfasına veya ana sayfaya bağlantı, kurumsal sosyal ağ sitelerine bağlantı, kurumsal bloga bağlantı ve işletmenin telefon numarasına bağlantıları içermektedir. Medya, haber 
bültenleri, medya odası, konuşmalar, politikalar, video ve ses ile endüstri haberlerine bağlantıları içermektedir. Yatırımcı ise yıllık raporlara bağlantılar ile işletmelerin web sitesinde bulunan yatırımcı ilişkileri sayfasına bağlantıları içermektedir. Ayrıca bu kısımda Twitter ortamında sıkça kullanılan etiket (hashtag), bir bağlantı olarak kabul edilmiş ve tüm etiketler değerlendirmeye alınmıştır. Bilginin yararlılığı kapsamında en çok görülen içerik, müşteri $(\mathrm{n}=475)$ olmuştur. Sonra medya $(\mathrm{n}=83)$ ve yatırımcl $(\mathrm{n}=1)$ gelmektedir.

\section{b. Tekrar ziyaretlerin korunmasi}

Tekrar ziyaretlerin korunması, güncellik ve bağlantı olarak iki kısımdan oluşmaktadır. Bir işletmenin hesabında bulunan son mesaj, 24 saat içinde atıldıysa bu hesap güncel kabul edilmiştir. Bu kapsamda hesapların büyük kısmının güncel $(n=55)$ olduğu görülmektedir. Bağlantı ise bilginin yararlılığı maddesi dışında kalan ve bu maddeyi destekleyecek biçimde işletme ürünlerinin veya hizmetlerinin açılamasını içeren bir sayfaya bağlantı, bunları anlatan video paylaşımı, vb. şekilde verilen bağlantılar bu başlık altında değerlendirilmiştir. Tüm mesajlar içinde paylaşılan çeşitli bağlantılar $(\mathrm{n}=27)$ bulunmaktadır.

\section{c. Tekrar ziyaretlerin sağlanması}

Tekrar ziyaretlerin sağlanması ise işletme hakkında bilgi, işletme hakkında ek bilgi, işletme ile ilgili gelişmeler, işletme hakkında medyada çıkan haberler ve işletme hakkında sorulan sorular olmak üzere beş başlkkla değerlendirilmiş ve bu başlklarla ilgili bağlantılar tespit edilmiştir. En sık karşılaşılan başlık, işletme hakkında bilgi ( $\mathrm{n}=323)$ olmuştur. Sonrasında işletme hakkında ek bilgi $(\mathrm{n}=276)$, işletmede yaşanan gelişmeler $(\mathrm{n}=21)$ ve işletme hakkında medyada çıkan haberler $(\mathrm{n}=18)$ gelmektedir. Ancak işletme hakkında sorulan sorular $(\mathrm{n}=0)$ ile ilgili bağlantı bulunmamaktadır.

\section{d. Diyalog döngüsü}

Diyalog döngüsü, temel olarak bir işletmenin diyalojik iletişimi teşvik etmek üzere bir soru sorması ya da bir kullanıcının gönderdiği bir soruya veya yoruma doğrudan cevap vermesi olarak düşünülmüştür. Ayrıca Twitter'nn beğen, retweet ve yorum özellikleri, işletme ile hedef kitlesi arasında etkileşim oluşturduğu için bir diyalog fırsatı olarak kabul edilmiştir. Bu kapsamda mesajlar içinde beğeni sayısı $(\mathrm{n}=681)$ oldukça fazladır, ikinci sırada retweet $(\mathrm{n}=471)$, mesajlara yapilan yorum $(\mathrm{n}=199)$ ise son sirada gelmektedir.

\section{AS.4: Hedef kitle}

Hedef kitleyi tespit edebilmek için çalışan, takipçi ve genel kitle şeklinde üç tür kitle belirlenmiştir. Yapılan incelemede mesajların büyük bir kısmının genel kitle $(\mathrm{n}=743)$, takipçi $(\mathrm{n}=14)$ ve çalşsan $(\mathrm{n}=12)$ şeklinde olduğu tespit edilmiştir.

\section{Tartışma}

Literatüre göre çeşitli işletmeler (kurumlar, kuruluşlar, STK'lar, vb.), web sitelerini (Aslan, 2017; Gordon ve Berhow, 2009; Özdemir ve Yamanoğlu, 2010) ve sosyal ağları (Bortree ve Seltzer, 2009; Rybalko ve Seltzer, 2010; Türkal ve Güllüpunar, 2017) diyalojik iletişim amacıyla kullanmamaktadır. Bu ortamlar genellikle işletmelerin yapmış olduğu faaliyetleri duyurmak, 
örgütsel haberleri ve güncel gelişmeleri paylaşmak için kullanılmaktadır. Dolayısıyla bu ortamların diyalojik iletişim potansiyelinden yararlanılmamaktadır. Twitter'ın diyalojik iletişim kurmak için uygun bir ortam sunduğu bilinmektedir. Ancak İSO 500 işletmeleri Twitter’ı diyalojik iletişimden ziyade yukarda belirtilen şekillerde kullandığı görülmektedir.

Kurumsal profil, kurumsal iletişim stratejisinin gelişimi için bir arka plan görevi görmektedir. Gerçek başlangıç noktası olarak kurumun vizyonu, misyonu, kültürü, kurumsal politikaları ve stratejileri hakkında eksiksiz bir bilgi ve anlayıştır (Steyn, 2000, s.14). Çalı̧̧ada, işletmelerin profilleri, kitlelerin işletmelere ulaşması ve erişmesi için bir imkan olarak düşünülmüştür. İşletmelerin büyük kısmı, resmi web sayfalarına bağlantı vermekte, Twitter ortamını örgütün web sayfası ile desteklemektedir. İşletmenin kısa açıklaması ve işletme sloganı, işletmenin kendini tanıtması için bir firsat niteliğindedir. Ancak işletmelerin neredeyse üçte biri bu imkandan yararlanmaktadır. Öte yandan işletme yeri bilgisi, iletişim noktalarından birisidir. Elde edilen sonuçlarda yabancı nitelikteki işletmelerin işletme yeri olarak Türkiye'yi seçtikleri, yerli işletmelerin ise bulundukları ili yazdıkları görülmüştür. Doğrudan mesaj, müşteri ile iletişim için kullanılabilecek alandır. İşletmelerin, takipçilerine doğrudan mesaj imkanı vermesi, diyalojik iletişimin önemli bir unsuru olarak düşünülmüştür. Sonuçlar, işletmelerin ancak yarısına yakınının böyle bir imkan sunduğunu göstermektedir. Diğer bağlantılar ile müşteriler, işletmenin diğer sosyal medya ortamlarına yönlendirilmektedir. Çok sayıda olmasa da bu şekilde paylaşım yapan işletmeler bulunmakta ve özellikle Facebook ile Instagram hesaplarına bağlantılar verilmektedir. Profil değerlendirmesinin son maddesi, Türkçe dışında kullanılan dillere yöneliktir. Bu kapsamda sadece beş işletmenin profilinde yer alan açıklamaların İngilizce verildiği görülmüştür. Bununla işletmelerin yabancı müşterilere hitap etmek istediği düşünülebilir.

İkinci araştırma sorusu ile mesaj içerikleri değerlendirilmiştir. Zira iletişim sürecinin en önemli unsurlarından birisi, paydaşlara gönderilecek mesajların içerikleridir. En sık kullanılan bilgi yayma stratejileri, kurumsal haberleri ve duyuruları iletmek, ürün ya da hizmet bilgilerini dağıtmaktır (Shin, Pang ve Kim, 2015, s.202). Elde edilen verilere göre en fazla paylaşılan içerik, işletme hakkındaki önemli bilgiler olmuştur. Diyalog oluşturmaya yönelik içerik, 40 işletmenin 154 mesajı ile ikinci sırada gelmektedir. Diyalojik iletişim açısından bu sonuç, hem işletme sayısı hem de mesaj sayısı açısından yeterli değildir. Diğer bir içerik ise önemli gün ve haftaların kutlanmasıdır. Yurt dışında yapılan çalışmalarda pek rastlanmayan bu tür mesaj içeriği, işletmelerin büyük kısmında görülmektedir. Ayrıca işletmelerin kendileri hakkında yapılan haberler ile sektörel haberleri paylaştıkları görülmüştür. Çalışmanın konusunu oluşturan, Twitter'ın buna imkan sağladığı ve diyalojik iletişim özelliklerinden biri olan, belirli bir kişiye cevap verme şeklinde değerlendirilebilecek bir içeriğe rastlanmamıştır. Mesajların diyalojik özelliklerinin değerlendirildiği ikinci sorudan elde edilen verilere göre işletmelerin Twitter'ı ağırlıklı olarak kurumsal haberleri aktarmak için kullandıkları söylenebilir. Bu sonuç, alan yazındaki çalışmalar (Linvill, McGee ve Hicks, 2012) ile benzerlik göstermektedir.

Üçüncü araştırma sorusu, mesajların diyalog ilkelerinin değerlendirilmesidir. Değerlendirme, dört başlıkta yapılmıştır. Bu başlıklardan ilki, bilginin yararlılı̆̆ıdır. Bu başlıkta elde edilen 
veriler, ikinci soruda elde edilen veriler ile paralellik göstermektedir. Müşteriye yönelik kurumsal haber bağlantılarının veya etiketlerin (hashtag) yoğun biçimde kullanıldığ görülmüştür. Tekrar ziyaretlerin korunması maddesine göre işletme hesaplarının büyük kısmı günceldir diğer bir deyişle çeşitli içerikteki paylaşımlarla hesaplar yenilenmektedir. Öte yandan sadece 9 işletmenin 27 mesajında işletmeye ait diğer sosyal medya ortamlarına (Facebook, Instagram, Youtube, vb.) bağlantılar verdiği görülmüştür. Tekrar ziyaretlerin sağlanması, işletmelerin yoğun olarak içerik ürettikleri ve paylaştıkları bir başlıktır. Bunun nedeni, bu başlığın özellikle işletmeyi tanıtıcı ve işletmeye yönelik bağlantıları içermesidir. Buraya kadar elde edilen verilere göre, mesaj içerikleri ve paylaşılan bağlantılar ile işletmelerin tam anlamıyla diyalojik iletişimi gerçekleştiremedikleri söylenebilir.

Üçüncü araştırma sorusunun son maddesi, diyalog döngüsüne yöneliktir. Diyalog döngüsü kapsamında beğeni ve retweet yüksek sayıda iken diyolojik iletişim özelliğini en çok yansıtan yorum sayısı diğerlerine göre daha düşüktür. Yorum yapılan mesajlar incelendiğinde yapılan yorumlara (sorular, şikayetler, vb.) cevap veren 11 işletme olduğu tespit edilmiştir. Cevapların özellikle olumsuz yorumlara verildiği görülmektedir. Verilen yanıtlar, çalışma konusunu ilgilendirdiği için aynen alınmış ancak işletme isimleri gizli tutulmuştur. Yorumlar aşağıdadır:

\section{İşletme 1.}

- Merhaba, ürünlerimizle ilgili geri dönüşleriniz bizim için çok değerli. Yardımcı olabilmemiz için size ulaşabileceğimiz bir telefon numarasını bize DM ile iletebilir misiniz?

- Merhaba, iletişim bilgilerinizi bize DM yoluyla iletebilirseniz, konuyu hemen yetkili birimlerimize aktarıp size yardımcı olmak isteriz.

- Merhaba Burhan Bey, süreç ile ilgili yorumunuzu hızlıca takip edilmesi için yeniden müşteri temsilcilerimize ilettik. Her türlü soru ve destek talebiniz için bize 7 gün 24 saat $4440^{*}$ no'lu telefonumuzdan ulaşabilirsiniz.

\section{İşletme 2.}

- Merhaba Hasan Bey, konuyla ilgili sizi bilgilendirebilmek için iletişim numaranızı direkt mesaj yoluyla paylaşabilir misiniz? Teşekkür ederiz.

- Merhaba, size memnuniyetle yardımcı olmak isteriz. İletişim bilgilerinizi direkt mesaj yoluyla bizimle paylaşabilir misiniz? Teşekkürler.

\section{İşletme 3.}

- Merhaba, Sorun yaşadığınız konuyla ilgili detaylı bilgiyi iletişim bilgilerinizle birlikte özel mesaj yoluyla bizimle paylaşabilirsiniz, size daha detaylı yardımcı olabiliriz.

- Merhaba, Sorun yaşadığınız konuyla ilgili bilgiyi bizimle paylaşabilirsiniz, size daha detaylı yardımcı olabiliriz.

\section{İşletme 4.}

- Merhaba, konuyla ilgili yardımcı olabilmemiz için iletişim bilgilerinizi mesaj olarak paylaşmanızı rica ederiz. Teşekkürler. 
- Merhaba @tusecim, arkadaşlarımız yoldalar şu an. İletişim bilgilerinizi DM yoluyla bize iletirseniz geçerken size de bir uğrayacaklar. Nasıl yapsak?

- Merhaba, belirtmiş olduğunuz konu ile ilgili size yardımcı olabilecek en yetkili birim Müşteri İletişim Merkezi'mizdir. Müşteri İletişim Merkezimize, 0850 numaralı telefondan ulaşabilirsiniz. Teşekkürler.

\section{İşletme 5 .}

- Merhaba, Öncelikle yaşadığınız problem için çok üzgün olduğumuzu ifade etmek isteriz. Bizimle DM’den iletişim bilgilerinizi paylaşırsanız hızlıca yardımcı olmak isteriz. Teşekkürler.

\section{İşletme 6.}

- Merhaba, iletişim bilgilerinizi bizimle paylaşır mısınız?

- Merhaba, ilginize teşekkür ederiz. İletişim bilgilerinizi bizimle paylaşır mısınız?

- Merhaba, konu hakkında sizi bilgilendirmemiz için iletişim bilgilerinizi bizimle paylaşır misiniz?

- Türk Gıda Kodeksi Beslenme ve Sağlık Beyanları Yönetmeliği’ne aşağıdaki linkten ulaşabilirsiniz.

\section{İşletme 7.}

- Merhaba, konuyla ilgili size yardımcı olabilmemiz için iletişim bilgilerinizi mesaj yoluyla paylaşmanızı rica ederiz.

- Merhaba, web sitemizi yeniliyoruz, kısa süreli hata almış olabilirsiniz. Konuyu yetkililerimize iletiyoruz. İlginiz için teşekkür ederiz.

- Merhaba, müşteri temsilcimizin en kısa zamanda sizinle iletişime geçebilmesi için iletişim bilgilerinizi mesaj yoluyla paylaşmanızı rica ediyoruz.

\section{İşletme 8.}

- Merhaba Serkan Bey, sizi bilgilendirebilmemiz için iletişim bilgilerinizi ve bulunduğunuz il-ilçeyi bizimle özel mesaj yoluyla paylaşabilir misiniz?

- Merhaba Cemil Bey, satı̧̧ fiyatımızı belirleyen en önemli faktör üretim maliyetimiz. Türk Standartlarına uygun olarak ürettiğimiz akülerimizin kalitesinin devamlılığı için üretim tesisimizde en son teknolojilere yatırımlar yapılıyor.

- Siz değerli müşterilerimizin en uygun fiyata akü satın alabilmesi için maliyetlerimiz sürekli inceleniyor ve gerekli optimizasyonlar yapilıyor.

- Tüketici ve rekabet kanunları gereği perakende satış fiyatına müdahale edememekle birlikte, en uygun fiyat akü satın alabilmeniz için maliyetlerimizin düşürülmesi ile ilgili çalışmalarımız devam edecektir. İlginize teşekkür ederiz.

\section{İşletme 9.}

- Merhaba, iletişim bilgilerinizi direkt mesaj olarak bizimle paylaşabilirseniz size en kısa sürede yardımcı olmak isteriz.

- Merhaba, konuyla ilgili * adresine mail atabilirsiniz. Sevgiler. 


\section{İşletme 10.}

- Osman Bey Merhaba, konuyla ilgili sizinle görüşebilmek için özel mesaj yolu ile iletişim bilgilerinizi iletmenizi rica ederiz.

- Merhaba, 29 yıllık tecrübelerimiz ve siz değerli tüketicilerimizin bildirimleri doğrultusunda sürekli gelişmeyi hedefliyoruz. Öneriniz pazarlama ekibimize iletilmiştir. Ürünlerimize her zaman güven duyacağınız düşüncesiyle bizlere ulaştığınız için teşekkür ederiz.

\section{İşletme 11.}

- Merhaba Ömer Bey, konu hakkında gerekli kontrollerin sağlanabilmesi için iletişim bilgilerinizi DM yoluyla paylaşabilir misiniz? İyi günler dileriz. ${ }_{-}^{*} \mathrm{DM}$ yanıt istiyorsunuz sorunu çözmek için yanıt veriyoruz cevap vermiyorsunuz.

- Merhaba, konu ile ilgili Canlı Destek hattımızdan detaylı bilgi alabilirsiniz. Canlı Destek

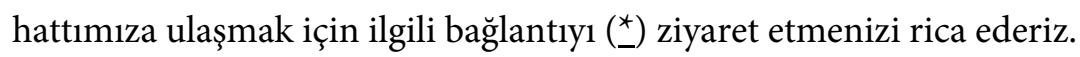

- Merhaba İbrahim Bey, tarafınıza DM yoluyla dönüşsağladık. Gelen kutunuzu kontrol etmenizi rica ederiz.

- Mehmet Bey, sizinle Facebook aracilığıyla iletişime geçildiğini görmekteyiz. Bize ulaştığınız için teşekkür ederiz

İşletmelerin Twitter'ı kurumsal bilgileri yaymak için kullanma oranları, diyalojik iletişim için kullanma oranından daha fazla olduğu görülmektedir. Bir kurum, diyaloğun gerçekleşebileceği bir ortam oluşturabilir ancak bunun başarısı, kurumun benimsediği felsefeye ve böyle bir ortamı oluşturmak için uygun kaynakları sağlamasına bağlıdır (Theunissen ve Noordin, 2012, s.11). Benzer bir çalışmada (Shin, Pang ve Kim, 2015), işletmelerin yarısından fazlası Twitter'daki müşteri yorumlarına veya sorularına yanıt vermesine rağmen, kişisel etkileşimlerin derecesi düşük çıkmıştır. Bu çalışmada ise incelenen 77 işletme arasından ancak 11 işletme cevap vermiş ve kişisel etkileşim yukarıda verilen şekilde gerçekleşmiştir.

Son araştırma sorusu, hedef kitlelerin belirlenmesine yöneliktir. Cornelissen (2014), hedef kitleyi bir işletmenin iletişim mesajlarıyla ulaşmak istediği önemli gruplar veya bireyler olarak tanımlamıştır. Elde edilen sonuçlar, mesajlarda çoğunlukla belirli bir hedef kitle bulunmadığı ve mesajların genel izleyici kitlesine yönelik olduğunu göstermektedir. Bu sonuç (Linvill, McGee ve Hicks, 2012) ile benzerlik göstermektedir.

\section{Sonuç}

Bu çalışmada, işletmelerin çevrimiçi ilişki kurma ve diyalojik iletişim uygulamalarını belirlemek üzere Twitter kullanımları incelenmiş, ülkemizin önde gelen işletmelerinin iletişim ve ilişki kurma hedeflerine ulaşmak için Twitter'ı nasıl kullandıklarına yönelik bilgiler sunulmuştur. Kent ve Taylor (2002)'ın diyalojik halkla ilişkiler teorisi, işletmelerin paydaşları ile iletişimlerini başarılı bir şekilde gerçekleştirmeleri ve sürdürmeleri için bir temel sağlamaktadır. Öte yandan sosyal medya, paydaşlarla etkileşimde bulunma, onlara doğrudan cevap verme ve onlarla ilişki kurma gibi durumlar için uygun bir araç olduğu düşünülmektedir ancak bu çalışmanın sonuçları, sosyal medyanın ve özellikle Twitter'ın paydaş katılımından ziyade kurumsal bilginin 
yayılması ve iki yönlü iletişimden daha çok tek yönlü iletişim için kullanıldığını göstermektedir. Diğer bir ifade ile işletmeler diyalojik iletişimlerini yürütmek için sosyal medyayı başarılı bir şekilde kullanamamaktadır (Rybalko ve Seltzer, 2010). Öyleyse ya sosyal medya ortamı düşünüldüğü gibi diyalojik iletişim için uygun değildir ve sosyal medyanın gerçek dünyada etkili bir iletişim aracı olması/kabulü sorgulanmalıdır (Taylor ve Kent, 2010) ya da işletmeler, bu ortamları nasıl kullanacağını bilememektedir. Dolayısıyla daha fazla araştırma, bu durumun nedenlerini ve Twitter gibi sosyal medya araçlarının ileride diyalojik iletişim için kullanılıp kullanılamayacağını ele almalıdır.

\section{Kaynakça}

Abitbol, A. and Lee, S. Y. (2017). Messages on CSR-Dedicated Facebook Pages: What Works and What Doesn't. Public Relations Review, 43(4), 796-808. doi: 10.1016/j.pubrev.2017.05.002

Argenti, P. A. (2006). How Technology Has Influenced the Field of Corporate Communication. Journal of Business and Technical Communication, 20(3), 357-370.

Aslan, A. (2017). Web Sitelerinin Birer Diyalojik İletişim Aracı Olarak Kullanımı Üzerine Bir Değerlendirme: Türkiye'deki Büyükşehir Belediyeleri Örneği, Süleyman Demirel Üniversitesi İktisadi ve İdari Bilimler Fakültesi Dergisi, 22(15), 2425-2436.

Bortree, D. S. and Seltzer, T. (2009). Dialogic Strategies and Outcomes: An Analysis of Environmental Advocacy Groups' Facebook Profiles. Public Relations Review, 35(3), 317319. doi: 10.1016/j.pubrev.2009.05.002

Botan, C. (1997). Ethics in Strategic Communication Campaigns: The Case for A New Approach to Public Relations. Journal of Business Communication, 34(2), 188-202.

Capozzi, L. and Zipfel, L. C (2012). The Conversation Age: The Opportunity for Public Relations, Corporate Communications: An International Journal, 17(3), 336-349. doi: $10.1108 / 13563281211253566$

Christensen, L. T., Morsing, M. and Cheney, G. (2008). Corporate Communications: Convention, Complexity and Critique. London: Sage.

Coombs, W. T. and Holladay, S. (2010). PR Strategy and Application: Managing Influence. New Jersey: Wiley-Blackwell. 
Cornelissen, J. (2014). Corporate Communication: A Guide to Theory and Practice. London: Sage.

Cutlip, S. M., Center, A. H. and Broom, G. M. (1985). Effective Public Relations. New Jersey: Prentice-Hall.

Eray, T. ve Aslan, A. (2016). Türkiye'de Siyasal Partilerin Web Sayfalarının Diyalojik İletişim Açısından İncelenmesi, İnönü Üniversitesi İletişim Fakültesi Elektronik Dergisi, 1(1), 112 121.

Gordon, J. and Berhow, S. (2009). University Websites and Dialogic Features for Building Relationships with Potential Students, Public Relations Review, 35, 150-152. doi:10.1016/j.pubrev.2008.11.003

Gutiérrez-García, E., Recalde, M. and Piñera-Camacho, A. (2015). Reinventing The Wheel? A comparative Overview of The Concept of Dialogue, Public Relations Review, 41(5), 744753. doi: 10.1016/j.pubrev.2015.06.006

Kent, M. L. and Taylor, M. (1998). Building Dialogic Relationships Through The World Wide Web, Public Relations Review, 24(3), 321-324.

Kent, M. L. and Taylor, M. (2002). Toward A Dialogic Theory of Public Relations, Public Relations Review, 28(1), 21-37. doi: 10.1016/S0363-8111(02)00108-X

Kwon, E. S. and Sung, Y. J. (2011). Follow Me! Global marketers' Twitter Use, Journal of Interactive Advertising, 12, 4-16. doi: 10.1080/15252019.2011.10722187

Linvill, D. L., McGee, S. E. and Hicks, L. K. (2012). Colleges' and Universities' Use of Twitter: A Content Analysis, Public Relations Review, 38(4), 636-638. doi: 10.1016/j.pubrev.2012.05.010

McAllister, S. M. (2012). How The World's Top Universities Provide Dialogic Forums for Marginalized Voices, Public Relations Review, 38(2), 319-327. doi: 10.1016/j.pubrev.2011.12.010 
Özdemir, B. P. ve Yamanoğlu, M. A. (2010). Türkiye'deki Sivil Toplum Kuruluşları Web Sitelerinin Diyalojik İletişim Kapasiteleri Üzerine Bir İnceleme, Ankara Üniversitesi Sosyal Bilimler Dergisi, 1(2), 3-36.

Özoran, B. A. (2017). Bir Halkla İlişkiler Ütopyası: Diyalojik Halkla İlişkiler, İstanbul Üniversitesi İletişim Fakültesi Dergisi, 53, 1-30.

Pollach, I. (2005). Corporate Self-presentation on the WWW: Strategies for Enhancing Usability, Credibility and Utility, Corporate Communications: An International Journal, 10(4), 285-301. doi: 10.1108/13563280510630098

Rybalko, S. and Seltzer, T. (2010). Dialogic Communication In 140 Characters or Less: How Fortune 500 Companies Engage Stakeholders Using Twitter, Public Relations Review, 36, 336-341. doi: 10.1016/j.pubrev.2010.08.004

Shin, W., Pang, A. and Kim, H. J. (2015). Building Relationships Through Integrated Online Media: Global Organizations' Use of Brand Web Sites, Facebook, and Twitter, Journal of Business and Technical Communication, 29(2), 184-220. doi: 10.1177/1050651914560569

Stephens, K. K. and Malone, P. C. (2009). If the Organizations Won't Give Us Information...: The Use of Multiple New Media for Crisis Technical Translation and Dialogue, Journal of Public Relations Research, 21(2), 229-239. doi: 10.1080/10627260802557605

Steyn, B. (2000). Model for Developing Corporate Communication Strategy, Communicare: Journal for Communication Sciences in Southern Africa, 19(2), 1-33.

Swani, K., Milne, G. R., Cromer, C. and Brown, B. P. (2013). Fortune 500 Companies' Use of Twitter Communications: A Comparison Between Product and Service Tweets. International Journal of Integrated Marketing Communications, 5(2), 47-56.

Theunissen, P. and Noordin, W. N. W. (2012). Revisiting The Concept Dialogue in Public Relations, Public Relations Review, 38(1), 5-13. doi: 10.1016/j.pubrev.2011.09.006

Türkal, İ. ve Güllüpunar, H. (2017). Diyalogsal Halkla İlişkiler Bağlamında Sosyal Medya Kullanımı: Türkiye'de İlk 100'de Yer Alan Şirketler Üzerine Bir İnceleme, Gümüşhane Üniversitesi İletişim Fakültesi Elektronik Dergisi, 5(2), 591-618. 
Waters, R. D. and Jamal, J. Y. (2011). Tweet, Tweet, Tweet: A Content Analysis of Nonprofit Organizations' Twitter Updates, Public Relations Review, 37(3), 321-324. doi: 10.1016/j.pubrev.2011.03.002

Waters, R. D. and Lemanski, J. L. (2011). Revisiting Strategic Communication's Past to Understand the Present, Corporate Communications: An International Journal, 16, 150169. doi: $10.1108 / 13563281111141679$

Yağmurlu, A. (2013). Diyalojik İletişim Çerçevesinden Ankara Büyükşehir Belediyesi Sosyal Medya Uygulamaları, Selçuk Üniversitesi İletişim Fakültesi Akademik Dergisi, 8(1), 95115. 